\title{
Physicians' Perception at College of Medicine/ University of Mosul Regarding Relationship with Drug Industries
}

\author{
Dr. Nadia Hazim Saeed \\ Department of Family and Community Medicine, College of Medicine, University of Mosul, Mosul, Iraq. \\ Correspondence: Nadia Hazim Saeed. nadia444@yahoo.com.
}

(Ann Coll Med Mosul 2019; 41 (1):).

Received: $7^{\text {th }}$ Apr. 2019; Accepted: $27^{\text {th }}$ May 2019.

\begin{abstract}
Context: Physicians experience a conflict of interest related to appropriate interaction to the current industries' practices of gifts provision as a marketing strategy.

Aim of the study: The study aims to explore physicians' insight about dealing with drug promotion activities of pharmaceutical industries.

Subjects and methods: A cross- sectional study design was conducted in the College of Medicine /University of Mosul during the academic year 2018-2019. Medical faculty staffs in the College of Medicine/ University of Mosul in the clinical departments including department of: (Medicine, Surgery, Pediatrics and Obstetrics and Gynecology). In addition to academic physicians in non-clinical departments who have privet clinic who agreed to participate were involved. A modified standardized questionnaire form was used.

Results: From 71 participant physicians 61 (85.92\%) had no previous teaching regarding ethical principles of interaction with drug representatives. Forty percent of the participants had personal friendship with a medical representative; meanwhile $63.38 \%$ had previous dealing with pharmaceutical companies. Only $16.9 \%$ of participants trust the information that delivered from drug companies. More than one fifth of participants supposed that gift provision from drug companies will influence drug prescription manners. Physicians considered drug sample appropriate gift to be accepted followed by conference registration fees, textbooks and travel to conference.

Conclusion and recommendations: Considerable proportion of academic Physicians at College of Medicine /University of Mosul had interaction with pharmaceutical company representatives. Academic physicians' responses attempted to minimize gifts provision on their professional behavior. However, pharmaceutical promotional activities should be monitored and controlled through physicians' self- regulation and legislations.
\end{abstract}

Keywords: Academic physicians, Pharmaceutical marketing, Professional behavioral, Drug representatives

$$
\begin{aligned}
& \text { إدراك الأطباء في كلية طب الموصل فيما يخص العلاقة مع شركات الأدوية } \\
& \text { فرع طب الأسرة و المجتمع، كلية الطبة، جامعقة الموصل، الموصل، العراق }
\end{aligned}
$$

المقدمة: يو اجه الأطباء تضاربًا في المصالح يتعلق بالإستجابة لممارسات شركات الصناعات الدوائية الحالية المتمثلة في تقديم الهدايا كستر اتيجية تسويقية.

الهـف من الاراسة: تهدف الدراسة إلى استكثاف وجهة نظر الأطباء حول التعامل مع أنشطة الثركات الدوائية في الترويج

المشاركون وطرق العمل: تم إجر اء تصميم در اسة مقطعية في كلية الطب / جامعة الموصل خلال العام الدراسي 2018-2019.

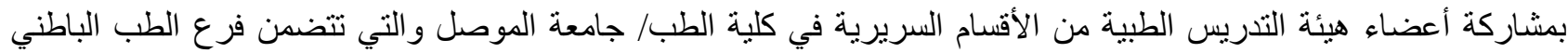


وفرع الجر احة وفرع الأطفال وفرع النسائية و التوليد، وكذلك الأطباء الأكادميين في الفروع الاساسية ممن لديهم عيادات خاصة

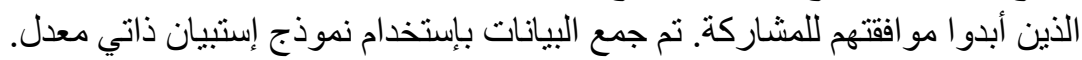

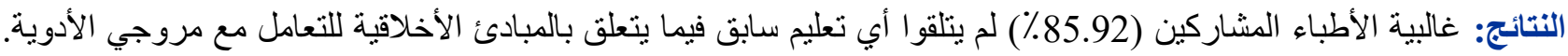

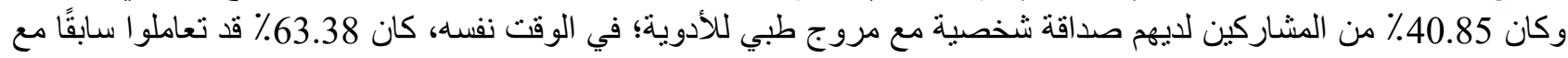

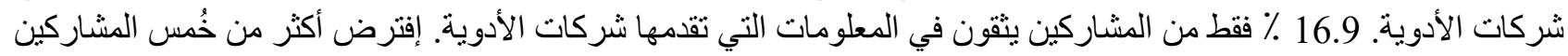

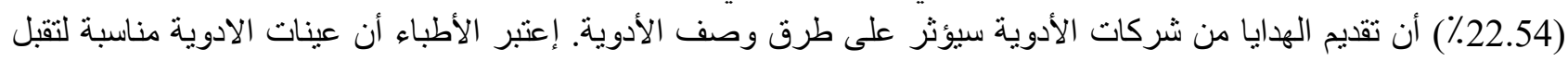

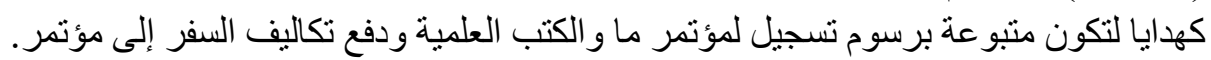

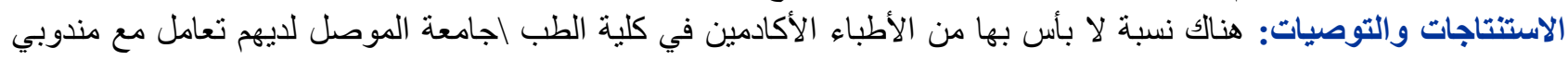

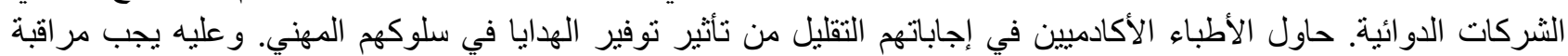

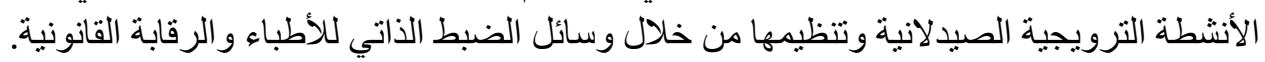

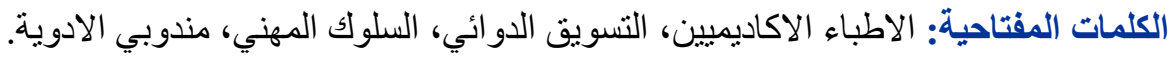

\section{INTRODUCTION}

$\mathrm{t}$ is well known that the primary duty of physicians is to manage their patients in a way that to achieve their best interest, avoid any harm, respecting their autonomy within a justifiable manner ${ }^{1-4}$. Indeed, pharmaceutical industry contribute for improving patient care via developing new medications, medical devices and products that support practicing modern medicine, conduct studies and executing clinical trials ${ }^{5}$.

However, with the great development of technology and complexity of medicine including pharmaceutical industry the medical care has been shifted to a commercial job resulting in a great competition in pharmaceutical industry ${ }^{6,7}$. Drug promotional strategies of pharmaceutical companies were directed toward physicians via gifts provision, funding of educational and social events ${ }^{8}$. Such strategies raised ethical worries linked to patients' rights since they are the primary consumers of pharmaceutical products ${ }^{7}$.

For instance, in a study conducted in US done in 20079 exposed that relationship with pharmaceutical industry was reported by most participants' physicians (94\%) mostly in the form of receiving food in the workplace $(83 \%)$ or receiving drug samples (78\%). In another Indian study that examined medical interns' attitude toward interaction with promotional activities of drug companies in $2017^{10}$. That study disclosed that one third $(32.2 \%)$ of them favored drug prescription from gifts providing companies over those without and majority $(77.8 \%)$ of the respondents thought that it is appropriate to accept gifts from drug representatives if offered. Likewise, according to a systematic review that identified studies conducted in low and middle-income countries revealed that the main benefits of physicians' interaction with pharmaceutical representatives were receiving information and rewards ${ }^{11}$.

Unfortunately, gifts provision can emerge a conflict of interest which may badly affect patients' trust and clinical care ${ }^{12}$. Therefore, physicians have to comprehend and manage their relationships with industry appropriately in order to safeguard their clinical and professional objectivity and avoid being in a conflict of interest ${ }^{13,14}$.

The present study aims to explore physicians' insight regarding promotional activities of pharmaceutical industries. The general aim was conducted through $1^{\text {st }}$ identifying physicians' previous teaching regarding medical ethics and their relation-ship with drug representatives. $2^{\text {nd }}$ exploring faculty staffs' attitude to drug representatives' promotional activities and $3^{\text {rd }}$ detecting their opinions to the appropriateness of accepting different types of pharmaceutical gifts.

\section{SUBJECTS AND METHODS}

A cross sectional study design was conducted in the College of Medicine/ University of Mosul. After obtaining the official permission, the medical faculty staffs' opinions regarding relationship with pharmaceutical companies were obtained via a modified standardized self-administered questionnaire form ${ }^{15}$. Data were collected during a period of two months from $1^{\text {st }}$ of Sep. 2018 to the $1^{\text {st }}$ of Nov 2018. The forms were circulated to all faculty staff in the clinical departments including 
department of: (Medicine, Surgery, Pediatrics and Obstetrics and Gynecology). In addition to academic physicians in non-clinical departments who have privet clinic. The participants were informed that participation is optional. The returned forms were 71 out of 177 (number of academic physicians of the College of Medicine / University of Mosul) forming response rates of $40.1 \%$.

The information that collected by the form was included general information of the participants that included their gender, age, years of professional experience, previous teaching regarding medical ethics and their relation-ship with drug representatives. In addition, the faculty staffs' attitude to drug representatives' promotional activities was obtained, and their opinions to the appropriateness of accepting different types of pharmaceutical gifts were included. The collected data arranged in suitable tables and managed statistically by the software Minitab version 14 . Simple descriptive statistical tools in the form of mean, standard deviation, numbers, percent and Z-test for one proportion were used for the presentation and analysis of the study results. Pvalue equal or less than 0.05 considered significant.

\section{RESULTS}

Out of 177 forms disseminated, 71 forms were returned forming response rate of $40.1 \%$. Table 1 shows that mean age of the study sample was 46.42 (SD 7.31), male forming $52.11 \%$. Significantly, more than three forth of the study sample $(77.46 \%)$ was having more than 10 years of professional experience. It was noticed that the majority of physicians $(83.1 \%)$ have no previous MEs teaching, as well as $85.92 \%$ had no previous teaching regarding ethical principles of interaction with drug representatives $(P=0.000)$. A proportion of $40.85 \%$ of the participants had personal friendship with a medical representative; meanwhile $63.38 \%$ had previous dealing with pharmaceutical companies.

Table 2 reveals that $71.83 \%$ of the participants physicians considered seminars that funded by drug companies are often unfair in approval of their products. While $56.34 \%$ of participants agreed on the beneficially of learning about new drugs from drug companies. On the other hand only $16.9 \%$ of participants trusted the information that delivered from drug companies, and $63.38 \%$ were neutrally trust. More than one fifth $(22.54 \%)$ of participants supposed that gift provision from drug companies will influence drug prescription manners.

According to the physicians opinion; drug sample considered appropriate gift to be accepted by $63.38 \%$ of the participants, followed by conference registration fees $(50.7 \%)$, textbooks $(43.66 \%)$, and travel to conference $(40.85 \%)$. While almost all participant refuse money as a promotional gifts as shown in Table 3.

Table (1): The percentage distribution of the study population according to their characteristics, $(n=71)$.

\begin{tabular}{|c|c|c|c|}
\hline Age $(n=71)$ & Mean & SD & $\begin{array}{c}\text { P- } \\
\text { value* }\end{array}$ \\
\hline & 46.42 & 7.31 & \\
\hline $\operatorname{Sex}(n=71)$ & No. & $\%$ & \\
\hline Male & 37 & 52.11 & \\
\hline Female & 34 & 47.89 & \\
\hline $\begin{array}{l}\text { Years of professional } \\
\text { experience }\end{array}$ & No. & $\%$ & \\
\hline$(1-5)$ & 3 & 4.23 & \\
\hline$(5-10)$ & 13 & 18.31 & \\
\hline 10 and above & 55 & 77.46 & \\
\hline $\begin{array}{l}\text { Proportion of physicians } \\
\text { how had previous MEs } \\
\text { education. }\end{array}$ & No. & $\%$ & \multirow{3}{*}{0.000} \\
\hline Yes & 12 & 16.9 & \\
\hline No & 59 & 83.1 & \\
\hline $\begin{array}{l}\text { Proportion of physicians } \\
\text { how had previous } \\
\text { teaching regarding } \\
\text { ethical principles of } \\
\text { interaction with drug } \\
\text { representatives of drug } \\
\text { companies }\end{array}$ & No. & $\%$ & \\
\hline Yes & 10 & 14.08 & \multirow{2}{*}{0.000} \\
\hline No & 61 & 85.92 & \\
\hline $\begin{array}{l}\text { Proportion of physicians } \\
\text { how had personal } \\
\text { friendship with a medical } \\
\text { representative. }\end{array}$ & No. & $\%$ & \multirow{3}{*}{0.154} \\
\hline Yes & 29 & 40.85 & \\
\hline No & 42 & 59.15 & \\
\hline $\begin{array}{l}\text { History of interaction by } \\
\text { Pharmaceutical company } \\
\text { representatives. }\end{array}$ & No. & $\%$ & \\
\hline Yes & 45 & 63.38 & \multirow{2}{*}{0.032} \\
\hline No & 26 & 36.62 & \\
\hline
\end{tabular}

* using Z-test for one proportion. 
Table (2): Physicians' perception regarding promotional activities of pharmaceutical companies, $(n=71)$.

\begin{tabular}{|c|c|c|c|}
\hline \multirow[b]{2}{*}{ Statements } & \multicolumn{3}{|c|}{ Physicians' responses } \\
\hline & $\begin{array}{l}\text { Agree } \\
\text { No. } \\
(\%)\end{array}$ & $\begin{array}{c}\text { No } \\
\text { opinion } \\
\text { No. \%) }\end{array}$ & $\begin{array}{c}\text { Disagree } \\
\text { No. (\%) }\end{array}$ \\
\hline $\begin{array}{l}\text { 1- Drug } \\
\text { representatives } \\
\text { deliver trustful } \\
\text { information about } \\
\text { their companies' } \\
\text { product. }\end{array}$ & $\begin{array}{c}12 \\
(16.9)\end{array}$ & $\begin{array}{c}45 \\
(63.38)\end{array}$ & $\begin{array}{c}14 \\
(19.72)\end{array}$ \\
\hline $\begin{array}{l}2 \text {-Drug } \\
\text { representatives } \\
\text { provide important } \\
\text { information to the } \\
\text { medical staff. }\end{array}$ & $\begin{array}{c}38 \\
(53.52)\end{array}$ & $\begin{array}{c}26 \\
(36.62)\end{array}$ & $7(9.86)$ \\
\hline $\begin{array}{l}\text { 3- Gifts from drug } \\
\text { companies can be } \\
\text { accepted because } \\
\text { they have minimal } \\
\text { effect on staff. }\end{array}$ & $\begin{array}{c}17 \\
(24.64)\end{array}$ & $\begin{array}{c}16 \\
(23.19)\end{array}$ & $\begin{array}{c}36 \\
(52.17)\end{array}$ \\
\hline $\begin{array}{l}\text { 4- Most of drug } \\
\text { companies' } \\
\text { informative activities } \\
\text { are helpful and } \\
\text { educational. }\end{array}$ & $\begin{array}{c}10 \\
(14.08)\end{array}$ & $\begin{array}{c}46 \\
(64.79)\end{array}$ & $\begin{array}{c}15 \\
(21.13)\end{array}$ \\
\hline $\begin{array}{l}\text { 5- It is beneficial to } \\
\text { learn about new } \\
\text { drugs from drug } \\
\text { companies. }\end{array}$ & $\begin{array}{c}40 \\
(56.34)\end{array}$ & $\begin{array}{c}27 \\
(38.03)\end{array}$ & $4(5.63)$ \\
\hline $\begin{array}{l}\text { 6-Drug companies } \\
\text { supported meetings } \\
\text { are often unfair in } \\
\text { approval of their } \\
\text { products. }\end{array}$ & $\begin{array}{c}51 \\
(71.83)\end{array}$ & $\begin{array}{c}20 \\
(28.17)\end{array}$ & $0(0.0)$ \\
\hline $\begin{array}{l}\text { 7-Drug companies' } \\
\text { gifts given to the } \\
\text { doctors will raise } \\
\text { costs of medicines. }\end{array}$ & $\begin{array}{c}28 \\
(39.44)\end{array}$ & $\begin{array}{c}13 \\
(18.31)\end{array}$ & $\begin{array}{c}25 \\
(35.21)\end{array}$ \\
\hline $\begin{array}{l}\text { 8- There is a chance } \\
\text { of increase } \\
\text { prescribing drug } \\
\text { from certain } \\
\text { companies that offer } \\
\text { gifts. }\end{array}$ & $\begin{array}{c}16 \\
(22.54)\end{array}$ & $\begin{array}{c}13 \\
(18.31)\end{array}$ & $\begin{array}{c}42 \\
(59.15)\end{array}$ \\
\hline $\begin{array}{l}\text { 9- Most drug } \\
\text { promotional and } \\
\text { adverting activities in } \\
\text { general are } \\
\text { unethical. }\end{array}$ & $\begin{array}{c}18 \\
(25.35)\end{array}$ & $\begin{array}{c}32 \\
(45.07)\end{array}$ & $\begin{array}{c}21 \\
(29.58)\end{array}$ \\
\hline
\end{tabular}

Table (3): Physicians' perception regarding the appropriateness of various promotional gifts of pharmaceutical companies, $(n=71)$.

\begin{tabular}{|c|c|c|c|}
\hline \multirow[b]{2}{*}{ Type of gift } & \multicolumn{3}{|c|}{ Physicians' responses } \\
\hline & $\begin{array}{l}\text { Appropriate } \\
\text { No. }(\%)\end{array}$ & $\begin{array}{l}\text { Inappropriate } \\
\text { No. (\%) }\end{array}$ & $\begin{array}{l}\text { Neutral } \\
\text { No. (\%) }\end{array}$ \\
\hline $\begin{array}{l}\text { 1- Restaurant } \\
\text { invitation }\end{array}$ & $6(8.45)$ & $\begin{array}{c}46 \\
(64.79)\end{array}$ & $\begin{array}{c}19 \\
(26.76)\end{array}$ \\
\hline 2- Drug sample & $\begin{array}{c}45 \\
(63.38)\end{array}$ & $\begin{array}{c}13 \\
(18.31)\end{array}$ & $\begin{array}{c}13 \\
(18.31)\end{array}$ \\
\hline 3 -Social journey & $5(7.04)$ & $\begin{array}{c}52 \\
(73.24)\end{array}$ & $\begin{array}{c}14 \\
(19.72)\end{array}$ \\
\hline $\begin{array}{l}4 \text {-Cash money } \\
(<20 \$)\end{array}$ & $0(0.0)$ & $\begin{array}{c}70 \\
(98.59)\end{array}$ & $1(1.14)$ \\
\hline $\begin{array}{l}\text { 5- Cash money } \\
(20-49 \$)\end{array}$ & $0(0.0)$ & $\begin{array}{c}70 \\
(98.59)\end{array}$ & $1(1.14)$ \\
\hline $\begin{array}{l}\text { 6- Cash money } \\
(\geq 50 \$)\end{array}$ & $1(1.14)$ & $\begin{array}{c}69 \\
(97.18)\end{array}$ & $1(1.14)$ \\
\hline $\begin{array}{l}\text { 7- International } \\
\text { Holiday }\end{array}$ & $3(4.23)$ & $\begin{array}{c}53 \\
(74.65)\end{array}$ & $\begin{array}{c}15 \\
(21.13)\end{array}$ \\
\hline 8- Notebook & $\begin{array}{c}20 \\
(28.17)\end{array}$ & $\begin{array}{c}33 \\
(46.48)\end{array}$ & $\begin{array}{c}18 \\
(25.35)\end{array}$ \\
\hline $\begin{array}{l}\text { 9-Conference } \\
\text { registration fees }\end{array}$ & $36(50.7)$ & $\begin{array}{c}20 \\
(28.17)\end{array}$ & $\begin{array}{c}15 \\
(21.13)\end{array}$ \\
\hline $\begin{array}{l}\text { 10- Travel to } \\
\text { conference }\end{array}$ & $\begin{array}{c}29 \\
(40.85)\end{array}$ & $\begin{array}{c}33 \\
(46.48)\end{array}$ & $\begin{array}{c}9 \\
(12.68)\end{array}$ \\
\hline 11- Stethoscope & $4(5.63)$ & $\begin{array}{c}49 \\
(69.01)\end{array}$ & $\begin{array}{c}18 \\
(25.35)\end{array}$ \\
\hline 12- Textbook & $\begin{array}{c}31 \\
(43.66)\end{array}$ & $\begin{array}{c}22 \\
(30.99)\end{array}$ & $\begin{array}{c}18 \\
(25.35)\end{array}$ \\
\hline
\end{tabular}

\section{DISCUSSION}

The current study is confined to academic physicians only who may have different perception and attitude than physicians who work in the health sectors which could related to the nature and field of work. However, academic physicians' perception was given an extra importance because they are role model and have direct influence on their students in medical colleges.

In the current study there is high proportion of physicians from the faculty staff of College of Medicine\ University of Mosul with no previous formal medical ethics (MEs) education or previous learning on the principles of interaction with drug representatives of pharmaceutical companies. This may be due to late establishment of MEs teaching in the College of Medicine\ University of Mosul at 2002 which is inadequate and still in the form of theoretical lectures with lack of postgraduate ethics education ${ }^{16}$. However, this result is convenient with a Saudi study conducted in 2014 in which only $(23 \%)$ of the participant physicians have history of 
education about the ethics of drug promotion as they reported ${ }^{15}$.

In regard to personal relationship and history of interaction with drug representative's numerous studies confirm such interaction. In a study in Germany on 2014 it was found that $84 \%$ of the physicians saw Pharmaceutical sales representatives at least once a week ${ }^{17}$. While an Indian study with a similar aim conducted in 2016; $37 \%$ of the responded doctors had interacted with medical representatives once a week whereas $25.9 \%$ of them disclosed that they interact with medical representatives twice a month ${ }^{18}$. Likewise, in a Nigerian study in 2017 depicted that all the participants doctors had visited by pharmaceutical sale representatives in the previous year and $(88.6 \%)$ of them visited 12 times or more in the last year ${ }^{19}$. In a systematic study done in 2017; Fickweiler, et al found that interaction with pharmaceutical sale representatives is common among attending physicians and residents ${ }^{20}$. The relatively less proportion of interaction with pharmaceutical sale representatives $(63.38 \%)$ as reported by participants' physicians in the current study may be because the participant was from the faculty staff of medical college.

In the current study it was found that $71.83 \%$ of the participants considered seminars that were funded by drug companies are often biased in favor of their products, more than half $(56.34 \%)$ of participants indicated that learning about new drugs from drug companies is helpful. Meanwhile, small proportions of participants $(16.9 \%)$ were trust the information from medical representatives about their companies' products. One fifth (22.54\%) considered gifts provision from pharmaceutical sale representatives could influence their drug prescription manners. In comparison to the Nigerian study in which two thirds of participants had positive attitude to drug promotion and $(47.6 \%)$ of them stated that drug promotion by pharmaceutical sale representatives would influence their prescription practices ${ }^{19}$. While in the Saudi study on 2014; Alosaimi FD et al, showed that $(52.1 \%)$ of the physicians denied that accepting pharmaceuticals' gifts could affect their own decisions, and $41.2 \%$ of the participants considered the promotional information from pharmaceutical sales representatives are inaccurate. More than one third $(37.9 \%)$ of the participants deliberated that drug information from pharmaceutical sales representatives will not influence their decisions ${ }^{21}$. On the other hand Fickweiler, et al in their systematic study in 2017; showed that large proportion of physicians assumed that information provided by pharmaceutical sale representatives, pharmaceutical funded conferences and continuous medical education (CME) events are helpful and educational. Also, they denoted that physicians do not consider that pharmaceutical sale representatives interactions influence their prescribing behavior in most of the studies, while other studies found that there was some extent of influence ${ }^{20}$. Whereas, in a national survey of physicians conducted in 2011in US showed that only $18 \%$ of the sample considered that information provided from pharmaceutical companies could influence the prescription decision, and only $17 \%$ of the participants considered promotional activities of pharmaceutical sale representatives apart from continuity medical education (CME) influence the Prescription decision ${ }^{22}$. The relative differences in the physicians' attitude in the current study and other studies may be due to differences in the characteristics of the participant regarding their years of experienced, qualifications and field of work. Actually academic physicians attempted to balance their interaction with pharmaceutical representative by minimizing the effect of promotional activities on their professional behavior. Mikhael et al, found that there is a significant difference in opinion regarding the reliability of promotional information between academic physicians who had have more negative opinion compared with physicians who work in hospitals. In that study medical representatives' information was considered useful by only hospital physicians ${ }^{23}$. In the same context, Brett et al revealed that faculty staff rated ethical concern for all study inquiries related to physicians interaction with pharmaceutical representatives and significantly for expensive and non-educational gifts ${ }^{24}$. In contrast, De Ferrari et al; found in their study in Peru (2014) that physicians who involved in teaching had more frequent interaction with pharmaceutical representatives than attending physicians and residents doctors. Furthermore, in that study faculty staff considered promotional gifts 
are ethically acceptable by $81.5 \%$ vs. attending physicians and residents by $58.3 \% ;(p=0.03) .{ }^{25}$

Almost all the academic physicians who participated in the present study refused cash money as a promotional gift. On the other hand, they considered drug appropriate gift to be accepted followed by conference registration fees, textbooks and travel to conference. Similarly, in Zaki study the most appropriate promotional gifts were conference registration fees and free drug samples $(67 \% \text { and } 66 \% \text {, respectively })^{15}$. Also, Richards in his national survey in US showed that $74 \%$ of physicians stated they accept drug samples from representatives. Most of them who accept samples use them to help patients ${ }^{22}$. While, Lieb and Scheurich found in their study that $69 \%$ of the participants' physicians accepted drug samples, 39\% accepted notebook and 37\% took part in funded continuing medical education ${ }^{17}$. In contrast, Morgan et al, found in their study that drug sample considered as a proper gift and is accepted by most respondents (92\%), an informational lunch by (77\%), while an anatomical model by $(75 \%)$ and a well-paid consultant ship (53\%) from pharmaceutical representatives ${ }^{26}$. Actually, although large proportion of physicians denied that gifts provision could influence their prescriptions behavior ${ }^{27}$. Yet, significant evidence revealed that gifts even of slight amount would influence behavior ${ }^{28,29}$.

\section{CONCLUSION AND RECOMMENDATIONS}

Promotional activities of pharmaceutical companies including gifts provision are globally common. Academic physicians' responses attempted to minimize gifts provision on their professional judgment. Physicians' interactions with pharmaceutical companies should be professional and directed to improve patient care. Legislations and monitoring should be activated to regulate drug promotional activities and appropriate physicians' behavior through selfregulation to support patients' welfare and safety.

\section{REFERENCES}

1. Williams $\mathrm{J} R$ : Medical ethics in contemporary clinical practice. Journal Chin Medical Association. 2005; 68(11):495.

2. Agarwal $\mathrm{R} \mathrm{K}$ : Ethics and ethical conflicts in contemporary medical practice. Indian Pediatrics 2008; 45 (17):177.
3. Parker M J: Getting ethics into practice: Clinicians need to be able to analyze and justify their day to day value judgments. BMJ 2004; 32 (17): 126-129.

4. The World Medical Association Policy: International code of medical ethics. Pilanesb June 17erg, South Africa, 2006.

5. Bansal R.K., Das S. Unethical relationship between doctors and drug companies. JIAFM 2005: 27 (1). 0971 0973.

6. Mandal BK, Yadav SK, Karn A, Sah AK. Relationship between Doctors and Pharmaceutical Industry: An Ethical Perspective. IJPBA 2012; 3(3):415-417.

7. Verma $S$ K. Physician-Pharmaceutical Industry Interaction: Changing Dimensions and Ethics. Indian $\mathrm{J}$ Pediate 2004; 41(17): 29-36.

8. The College of Physicians and Surgeons of Ontario. Physicians' Relationships with Industry: Practice, Education and Research, 2014.

9. Campbell E G, Gruen R L, Mountford J, Miller LG, Cleary PD, Blumenthal $D$, et al. A National Survey of Physician-Industry Relationships. N Engl J Med 2007; 356:1742-1750.

10. Chandan NG, Shashikumar N S, Nagabushan H. Pharmaceutical drug promotion: perception and attitude of medical interns towards drug company interactions in a tertiary care teaching hospital. Int $J$ Basic Clin Pharmacol 2017;6(6):1456-1460.

11. LotfiT, Morsi R Z., Rajabbik M H, Alkhaled L, Kahale $L$, Nass $H$, Brax $H$, Fadlallah $R$ and Elie A. Knowledge, beliefs and attitudes of physicians in low and middleincome-countries regarding interacting with pharmaceutical companies: a systematic review. BMC Health Services Research (2016) 16:57.

12. McFadden DW, Calvario $E$ and Graves $C$. The devil is in the details: The pharmaceutical industry's use of gifts to physicians as marketing strategy. J Surg Res 2007;140:1-5.

13. Malaysian Medical Council. Relationship between doctors and the pharmaceutical industry. 2006.

14. Grande D. Limiting the Influence of Pharmaceutical Industry Gifts on Physicians: Self-Regulation or Government Intervention? J Gen Intern Med 2009; 25(1):79-83.

15. Zaki N M. Pharmacists' and physicians' perception and exposure to drug promotion: A Saudi study. S P J 2014; 22, 528-536.

16. Saied NH. Developing a New Undergraduate Teaching Module in Medical Ethics in the College of Medicine at University of Mosul. PhD Thesis. The University of Mosul. 2017.

17. Lieb K, Scheurich A. Contact between Doctors and the Pharmaceutical Industry, Their Perceptions, and the Effects on Prescribing Habits; PLoS ONE. 2014; 9(10): e110130.

18. Gupta SK, Nayak RP, Sivaranjani R. A study on the interactions of doctors with medical representatives of pharmaceutical companies in a Tertiary Care Teaching Hospital of South India. J Pharm Bioallied Sci. 2016; 8(1):47-51

19. Pascal Iloh GU, Chukwuonye ME. Drug promotion in a resource-constrained Nigerian environment: A crosssectional study of the influence of pharmaceutical sales representatives on the prescribing behaviors of medical 
practitioners in Abia State. Arch Med Health Sci 2017;5:215-22.

20. Fickweiler F, Fickweiler W, Urbach E. Interactions between physicians and the pharmaceutical industry generally and sales representatives specifically and their association with physicians' attitudes and prescribing habits: a systematic review. BMJ Open 2017;7:e016408. doi:10.1136/bmjopen-2017-016408.

21. Alosaimi FD, Al Kaabba A, Qadi M, Albahlal A., Alabdulkarim Y, Alabduljabbar M, Alqahtani F. Physicians' attitudes towards interaction with the pharmaceutical industry. EMHJ 2014; 20 (12): 812-819.

22. Richards M D. Survey of Physicians about Pharmaceutical and Biotech Research Company Activities and Information. KRC Research 2011, www.krcresearch.com.

23. Mikhael E M, ALHilali D N, AL Mutawall B Z, Toma N $M$. The reliability and accuracy of medical and pharmaceutical information that were given by drug companies through medical representatives to Iraqi physicians. Int J Pharm Pharm Sci 2014; 6 (1): 627-630.

24. Brett AS, Burr W, Motoo J. Are gift from pharmaceutical companies ethically problematic? A survey of physicians. Arch Intern Med 2003;163:22132218.

25. De Ferrari A, Gentille C, Davalos L, Huayanay L, Malaga $G$ Attitudes and Relationship between Physicians and the Pharmaceutical Industry in a Public General Hospital in Lima, Peru. PLoS ONE 2014; 9(6): e100114.

26. Morgan M A, Dana J, Loewenstein G, Zinberg S, Schulkin J. Interactions of doctors with the pharmaceutical industry. J Med Ethics 2006;32: 559563.

27. Patwardhan AR. Physicians-Pharmaceutical Sales Representatives Interactions and Conflict of Interest: Challenges and Solutions. INQUIRY; 2016,53: 1-5.

28. Katz D, Caplan A L, Merz JF. All Gifts Large and Small; Toward an Understanding of the Ethics of Pharmaceutical Industry Gift-Giving. AJOB 2003; 3, 3: 39-46.

29. Dana J, Loewenstein G. A social science perspective on gifts to physicians from industry. JAMA 2003; 209 (2):252-255. 